\title{
PERDEDAAN TERAPI MASSAGE DAN TERAPI RELAKSASI DALAM MENGURANGI NYERI PERSALINAN DI BIDAN PRAKTIK SWASTA (BPS) ERNAWATI KECAMATAN BANYUMAS
}

\author{
Sunarsih $^{1}$, Ernawati $^{2}$ \\ ${ }^{1,2}$ Program Studi Kebidanan, Universitas Malahayati Bandar Lampung \\ Email: sunarsih.unmal@yahoo.com
}

\begin{abstract}
Difference of Massage and Relaxed Therapy in Relieving Labor Pain at Ernawati's Health Center, Banyumas Subdistrict. Labor Pain can cause uncoordination of uterus activity, it led long labor and finally threaten fetus' and mother's life. Various efforts were done to relieve the pain at labor, such as massage therapy and relaxed technique. The survey result at Ernawati's Health Centertoward, there were five labor's women, $80 \%$ of them said that they felt pain which could not be endurable at the time of labor process, but it relieved after done massage and relaxation. This research was to known difference of massage and relaxed therapy in relieving labor pain at Ernawati's Health Center, Banyumas Subdistrict, in 2016. it was quantitative research by quasi-experimental design, held on 12th March to 25th July 2016. Population were all mothers who would give a birth, about 31 women, total sample were 40 women. Sampling technique was systematic sampling technique. The variables in this study were massage therapy, relaxed techniques and labor pain. Data analized by using T-test. The result showed that the average of labor pain before and after given massage were 6,90 and 4,90, respectively. Mean differences was 2,0 . Then, the average of labor pain before and after given relaxed technique were 6,90 and 5,25, respectively. Mean differences was 1,65 . The result of statistic test, $p$-value $=0,000$. It means that there were difference between massage and relaxed therapy in relieving labor pain at Ernawati's Health Center, Banyumas Subdistrict in 2016.
\end{abstract}

Keywords: Relaxed technique, Massage therapy, Labor pain

\begin{abstract}
Abstrak: Perbedaan Terapi Massage dan Terapi Relaksasi dalam Mengurangi Nyeri Persalinan di Bidan Praktik Swasta (BPS) Ernawati Kecamatan Banyumas. Nyeri persalinan dapat menyebabkan aktivitas uterus yang tidak terkoordinasi yang akan mengakibatkan persalinan lama, yang akhirnya dapat mengancam kehidupan janin dan ibu. Berbagai upaya dilakukan untuk menurunkan nyeri pada persalinan, antara lain dengan terapi massage dan teknik relaksasi. Hasil survey di Bidan Praktik Swasta (BPS) Ernawati kepada 5 orang ibu bersalin didapat sebanyak $80 \%$ orang mengatakan nyeri yang tidak tertahan saat proses persalinan namun berkurang setelah dilakukan massage dan relaksasi. Tujuan penelitian diketahui berbedaan terapi massage dengan terapi relaksasi dalam mengurangi nyeri persalinan di BPS Ernawati Kecamatan Banyumas tahun 2016.Penelitian kuantitatif dengan rancangan quasi eksperimen. Penelitian dilaksanakan pada tanggal 12 Maret 2016 sampai dengan 25 Juli tahun 2016. Populasi dalam penelitian ini adalah seluruh ibu yang akan melahirkan rerata 31 orang, sampel berjumlah 40 orang,teknik sampling yang digunakan dalam penelitian ini adalah sistematik sampling. Variabel penelitian terapi massage, teknik relaksasi dan nyeri persalinan. Analisis data uji statistik dengan uji t. Hasil penelitian didapatkan rata-rata nyeri persalinan sebelum diberikan massage adalah 6,90 dengan dan setelah adalah 4,90 dengan beda mean 2,0, rata-rata nyeri persalinan sebelum diberikan teknik relaksasi adalah 6,90 dan setelah adalah 5,25 dengan beda mean 1,65. Hasil uji statistik nilai $p$ value $=0,000$ yang berarti terdapatperbedaan terapi massage dengan terapi relaksasi dalam mengurangi nyeri persalinan di BPS Ernawati Kecamatan Banyumas tahun 2016. Petugas Kesehatan diharapkan lebih meningkatkan keterampilan dalam pengurangan rasa nyeri non farmakologi, seperti massagedan relaksasi dengan benar sehingga pasien merasa nyaman.
\end{abstract}

Kata kunci: Teknik relaksasi, Terapi massage, Nyeri persalinan

Persalinan dan kelahiran merupakan kejadian fisiologis yang normal. Persalinan dan kelahiran normal adalah proses pengeluaran janin yang terjadi pada kehamilan cukup bulan (37-42 minggu), lahir spontan dengan presentasi belakang kepala yang berlangsung dalam 18 jam, tanpa komplikasi baik pada ibu maupun pada janin (Manuaba, 2010). 
Nyeri pada proses persalinan diakibatkan karena peregangan segmen bawah rahim selama kontraksi servik. Kontraksi pada saat melahirkan akan menimbulkan perasaan nyeri yang timbul akibat kontraksi servik serta dilatasi (pelebaran) mulut rahim dan segmen bawah rahim.Intensitas nyeri sebanding dengan kekuatan kontraksi dan tekanan yang terjadi, nyeri bertambah ketika mulut rahim dalam keadaan dilatasi penuh akibat tekanan bayi terhadap stuktur panggul diikuti regangan dan perobekan jalan lahir. Lebih dari itu, berbagai hambatan fisik dan psikologis pada ibu saat persalinan akan menambah rasa nyeri yang terjadi (Mender, 2013).

Berbagai upaya dilakukan untuk menurunkan nyeri pada persalinan, baik secara farmakologi maupun nonfarmakologi. Manajemen nyeri secara farmakologi lebih efektif dibanding dengan metode nonfarmakologi, namun metode farmakologi lebih mahal, dan berpotensi mempunyai efek yang kurang baik. Sedangkan metode nonfarmakologi lebih murah, simple, efektif dan tanpa efek yang merugikan (Mender, 2013).

Salah satu metode yang sangat efektif dalam menanggulangi nyeri adalah dengan massage dan relaksasi yang merupakan salah satu metode nonfarmakologi yang dilakukan untuk mengurangi nyeri persalinan. Bidan mempunyai andil yang sangat besar dalam mengurangi nyeri nonfarmakologi. Intervensi yang termasuk dalam pendekatan nonfarmakologi adalah analgesia psikologis yang dilakukan sejak awal kehamilan, relaksasi, massage, stimulasi kuteneus, aroma terapi, hipnotis, akupuntur dan yoga (Gadysa, 2009). Cara-cara untuk mengurangi rasa sakit antara lain: pijatan ganda pada pinggul, relaksasi, kompres panas dan dingin dan lain-lain (Nurasiah, 2012).

BPS Ernawati merupakan BPS yang terletak di Kecamatan Banyumas, berdasarkan data rekam medik BPS Ernawati, jumlah ibu bersalin tahun 2014 sebanyak 396 persalinan, tahun 2015 sebanyak 389 persalinan dan tahun 2016 selama periode bulan Januari-April sebanyak 129 persalinan (BPS Ernawati, 2016).

Berdasarkan dari hasil prasurvey yang dilakukan pada tanggal 12-17 Maret 2016, yang dilakukan di BPS Ernawati pada 5 orang pasien yang akan melahirkan, didapati sebanyak 4 $(80 \%)$ orang mengatakan nyeri yang tidak tertahan saat proses persalinan namun nyeri berkurang setelah dilakukan massage sebanyak 2 orang dan relaksasi sebanyak 2 orang.

\section{METODE PENELITIAN}

Penelitian ini adalah penelitian kuantitatif yaitu suatu metode yang berlandaskan pada filsafat positifisme digunakan untuk meneliti pada populasi atau sampel tertentu, pengumpulan data menggunakan instrumen penelitian, analisis data bersifat kuantitatif dengan tujuan untuk menguji hipotesis yang telah ditetapkan (Sugiyono, 2012). Desain penelitian ini adalah quasi eksperimen atau eksprimen semudengan pendekatan nonequivalent control group Design. Dalam rancangan ini, pengelompokan anggota sampel pada kelompok esperimen dan kelompok kontrol tidak dilakukan secara random atau acak (Notoatmodjo, 2010). Penggunaan desain tersebut atas pertimbangan bahwa tidak adanya pengendalian yang ketat terhadap sampel. Penelitian telah dilaksanakan pada tanggal 12 Maret 2016sampai dengan 25 Juli tahun 2016, tempat penelitian di BPS Ernawati Kecamatan Banyumas.

Populasi dalam penelitian ini adalah seluruh ibu dalam proses persalinan di BPS Ernawati Kecamatan Banyumas, rata-rata setiap bulan berjumlah 31 orang, jumlah sampel yang digunakan sebanyak 40 orang yang didapat dengan teknik sistematik sampling. Variabel yang digunakan dalam penelitian meliputi variabel bebas: massagedan teknik relaksasi sedangkan variabel terikat berupa nyeri persalinan. Analisa data univariat dan bivariat dilakukan dengan program komputer. Analisa univariat dengan menggunakan tabel distribusi frekuensi dan analisa bivariat dengan menggunakan uji t ( $t$-test).

\section{HASIL}

\section{A. ANALISIS UNIVARIAT}

Tabel 1. Intensitas Nyeri Persalinan Sebelum dan Setelah Dilakukan Massage

\begin{tabular}{lccccc}
\hline $\begin{array}{c}\text { Intensitas } \\
\text { Nyeri }\end{array}$ & Mean & $\begin{array}{c}\text { Std. } \\
\text { Deviation }\end{array}$ & Min & Max & n \\
\hline $\begin{array}{l}\text { Sebelum terapi } \\
\text { massage }\end{array}$ & 6.90 & 0,641 & 6 & 8 & 20 \\
\hline $\begin{array}{l}\text { Setelah terapi } \\
\text { massage }\end{array}$ & 4.90 & 0,788 & 4 & 6 & 20 \\
\hline
\end{tabular}

Berdasarkan tabel 1 dari 20 reponden diketahui bahwa mean intensitas nyeri sebelum dilakukan terapi massage 6,90 dengan nilai skala nyeri minimum 6 dan nilai maksimum 8 , dan standar deviasi 0,641 . Sedangkan serelah terapi massage didapatkan mean 4,90 dengan nilai skala 
nyeri minimum 4 dan nilai maksimum 6 dan standar deviasi 0,788 .

Tabel 2. Intensitas Nyeri Persalinan Sebelum dan Setelah Dilakukan Teknik Relaksasi

\begin{tabular}{lccccc}
\hline $\begin{array}{l}\text { Intensitas } \\
\text { Nyeri }\end{array}$ & Mean & $\begin{array}{c}\text { Std. } \\
\text { Deviation }\end{array}$ & Min & Max & n \\
\hline $\begin{array}{l}\text { Sebelum terapi } \\
\text { relaksasi }\end{array}$ & 6.90 & 0,788 & 6 & 8 & 20 \\
\hline $\begin{array}{l}\text { Setelah terapi } \\
\text { relaksasi }\end{array}$ & 5.25 & 0,724 & 4 & 7 & 20 \\
\hline
\end{tabular}

Berdasarkan tabel 2 diketahui bahwa dari 20 responden didapatkan mean intensitas nyeri sebelum dilakukan tarapi relaksasi adalah 6,90 dengan nilai skala nyeri minimum 6 dan nilai maksimum 8 dan standar deviasi 0,788. Sedangkan setelah dilakukan terapi relaksasi didapatkan mean 5,25 dengan nilai skala nyeri minimum 4 dan nilai maksimum 7 dan standar deviasi 0,724 .

\section{B. ANALISIS BIVARIAT}

Tabel 3. Terapi Massage dan Terapi Relaksasi dalam Mengurangi Nyeri Persalinan

\begin{tabular}{lrrrrrr}
\hline Nyeri Persalinan & Mean & Beda Mean & SD & t-test & p-value & $\boldsymbol{n}$ \\
\hline Sebelum Massage & 6.90 & 2.00 & 0.918 & 9,747 & 0.000 & 20 \\
Setelah Massage & 4.90 & & & & & \\
\hline Sebelum Relaksasi & 6.90 & 1.65 & 0.587 & 12,568 & 0.000 & 20 \\
Setelah Relaksasi & 5.25 & & & & & \\
\hline
\end{tabular}

Berdasarkan hasil analisis uji bivariat pada tabel 3 di atas, diketahui distribusi rerata nyeri persalinan pada kelompok yang dilakukan massage dengan penilaian dari 6,90 turun sebesar 2,0 menjadi 4,90, hasil uji statistik didapatkan ttest $>\mathrm{t}_{\text {-tabel }}$ yaitu $9,747>1.725$ p-value $=0,000 \quad(<\alpha$ $0,05)$ yang berarti ada pengaruh massage dalam mengurangi keluhan nyeri persalinan. Pada kelompok relaksasi dari 6,90 turun sebesar 1,65 menjadi 5,25 , hasil uji statistik didapatkan $\mathrm{t}_{\text {test }}>\mathrm{t}$ tabel yaitu 12,568>1.725 $p$-value $=0,000(<\alpha 0,05)$ yang berarti ada pengaruh massage dengan nyeri persalinan. Sehingga dapat disimpulkan bahwa massage lebih efektif jika dibandingkan relaksasi dalam pengurangan nyeri persalinan.

\section{PEMBAHASAN}

Rerata nyeri persalinan pada kelompok yang dilakukan massageadalah 6,90 turun sebesar 2,0 menjadi 4,90, hasil uji statistik didapatkan $\mathrm{t}_{\text {-test }}>\mathrm{t}_{\text {-tabel }}$ yaitu $9,747>1.725 \quad p$ value $=0,000 \quad(<\alpha \quad 0,05)$ yang berarti ada pengaruhmassage dalam mengurangi keluhan nyeri persalinan. Pada kelompok relaksasi rerata nyeri persalinan sebelum dilakukan intervensi adalah 6,90 turun sebesar 1,65 menjadi 5,25, hasil uji statistik didapatkan $\mathrm{t}_{\text {-test }}>\mathrm{t}$ tabel yaitu $12,568>1.725 p$-value $=0,000 \quad(<\alpha \quad 0,05) \quad$ yang berarti ada pengaruh massage dengan nyeri persalinan. Terlihat perbedaan nilai mean antara kelompok massage dan kelompok yang diberikan teknik relaksasi, sehingga dapat disimpulkan bahwa massage lebih efektif jika dibandingkan relaksasi dalam pengurangan nyeri persalinan.
Ibu yang mengalami persalinan pasti mengalami nyeri. Nyeri yang dirasakan saat bersalin amat subyektif bagi setiap ibu. Rasa nyeri persalinan bersifat personal, setiap orang mempersepsikan rasa nyeri yang berbeda terhadap hasil stimulus yang sama tergantung pada ambang nyeri yang dimilikinya. Nyeri pada persalinan adalah manifestasi dari adanya kontraksi (pemendekan) otot rahim. Sebagian besar ibu menganggap dan membayangkan nyeri persalinan sebagai suatu hal atau pengalaman yang menakutkan (Andarmoyo dan Suharti, 2013).

Manifestasi fisiologis dari nyeri yang paling sering adalah peningkatan nadi dan kecepatan pernafasan, pupil berdilatasi/ melebar, peningkatan tekanan darah, dan ketegangan otot. Peningkatan tegangan otot merupakan yang paling didasarkan karena bisa menghalangi kemajuan persalinan. Ibu dalam persalinan seringkali menguatkan otot-otot tulang selama kontraksi dan tetap tidak bergerak. (Maryunani, 2010).

Penatalaksanaan nyeri dapat berupa terapi farmakologis maupun non farmakologis. Penatalaksanaan nyeri secara farmakologis dapat menimbulkan efek samping pada ibu bersalin maupun janin, sedangkan terapi non farmakologis dianggap sangat aman seperti: relaksasi, hipnoterapi, imajina, massage, sentuhan terapeutik, akupresur, akupuntur, musik, dll (Berman, et al. 2009).

Massage adalah stimulasi kutaneus tubuh secara umum, sering dipusatkan pada punggung dan bahu. Massage tidak secara spesifik menstimulasi reseptor tidak nyeri pada bagian 
yang sama seperti reseptor nyeri tetapi dapat mempunyai dampak melalui sistem kontrol desenden. Massage dapat membuat pasien lebih nyaman karena menyebabkan relaksasi otot (Smeltzer dan Bare, 2002).

Relaksasi otot skeletal dipercaya dapat menurunkan nyeri dengan merilekskan ketegangan otot yang menunjang nyeri. Hampir semua orang dengan nyeri kronis mendapatkan manfaat dari metode relaksasi. Periode relaksasi yang teratur dapat membantu untuk melawan keletihan dan ketegangan otot yang terjadi dengan nyeri kronis dan yang meningkatkan nyeri (Smeltzer dan Bare, 2012).

Hasil penelitian ini sejalan dengan penelitianWirya \& Duma (2011) yang melakukan penelitian dengan sampel pasien post appendiktomi yang berjumlah 12 kelompok massage punggung dan relaksasi nafas dalam. Berdasarkan hasil analisis bivariat dengan menggunakan uji $T$ Berpasangan didapatkan adanya perbedaan nilai rata-rata tingkat nyeri sebelum dan setelah perlakuan sebesar 1,75. Dari hasil analisis statistik dengan menggunakan uji $T$ Berpasangan didapatkan nilai $p=0,017<\alpha=0,05$ dimana ada perbedaan bermakna antara pre dan post intervensi, maka dapat disimpulkan bahwa ada pengaruh pemberian massage punggung dan teknik relaksasi nafas dalam yang signifikan terhadap penurunan intensitas nyeri pada pasien post Appendiktomi.

Menurut peneliti, terjadinya pernurunan intensitas nyeri ibu bersalin sebelum dan setelah diberikan massage maupun relaksasi dikarenakan kedua intervensi tersebut memberikan efek yang hampir sama yaitu menghilangkan nyeri. Tehnik massage diberikan dengan melakukan pijatan ringan pada bagian abdomen ibu yang merupakan pusat dari rasa nyeri akibat kontraksi uterus. Pijatan ringan yang dilakukan dapat meningkatkan relaksasi otot sehingga dapat memutuskan siklus feartension-pain(takuttegang-nyeri). Sedangkan teknik relaksasi dilakukan saat kontraksi sedang belangsung, penghirupanudara yang maksimal mengakibatkan suplai oksigen pada uterus cukup sehingga hal tersebut dapat mengurangi ketegangan pada otot juga mengurangi rasa takut atau kecemasan yang ada pada diri pasien.

Persalinan juga perlu didukung oleh kondisi psikologi pasien yang baik, hal itu juga yang menjadi salah satu faktor keberhasilan intervensi yang diberikan. Psikologi yang baik dapat terjadi karena berbagai hal yaitu adanya dukungan dari suami dan kondisi ibu yang percaya diri dalam menjalani persalinan sehingga ibu tidak merasakan nyeri persalinan yang berat. Wanita yang secara psikologis cukup baik yakin bahwa persalinan merupakan hal yang normal sehingga ibu benar-benar siap dalam menghadapi persalinan, mengesampingkan nyeri dengan mengutamakan pengharapan akan lahirnya bayi yang telah lama dinantikan. Selain itu, paritas ibu mempengaruhi kesiapan ibu dalam mengahapi persalinan, pengalaman yang baik tentang persalinan sebelumnya akan membuat ibu berasumsi bahwa persalinan bukanlah sesuatu yang menyakitkan.

Nyeri persalinan disebabkan oleh adanya kontraksi otot-otot uterus, selain itu terdapat beberapa faktor yang turut berpengaruh diantaranya yaitu riwayat kehamilan, kurangnya dukungan keluarga dan persepsi yang buruk tentang persalinan hal tersebut yang menyebabkan beberapa pasien masih merasakan nyeri dan tidak mengalami penurunan yang berarti.

\section{SIMPULAN}

Ada perbedaan terapi massage dengan terapi relaksasi dalam mengurangi nyeri persalinan di BPS Ernawati Kecamatan Banyumas tahun 2016 (t 12,568> 1,725 p-value $0,000$ dan $\mathrm{t} 9,747>1,725$-value 0,000$)$.

\section{SARAN}

\section{Tempat Penelitian}

a. Diharapkan untuk selalu dapat menerapkan menajemen nyeri non farmakologi seperti massage dan relaksasi sebagai bentuk asuhan sayang ibu bayi terutama pada saat bersalin.

b. Diharapkan untuk dapat memperhatikan kebutuhan psikologi ibu saat bersalin sehingga persalinan dapat berlangsung dengan normal dan mempermudah dalam menerapkan intervensi massage maupun relaksasi

\section{Bagi peneliti lainnya}

Diharapkan peneliti lainnya dapat melanjutkan penelitian ini agar dapat lebih menyempurnakan hasil penelitian ini dengan menambah variabel-variabel lain berhubungan dengan tehnik pengurangan rasa nyeri. 


\section{DAFTAR PUSTAKA}

Andarmoyo.S., Suharti. 2013.Persalinan Tanpa Nyeri Berlebihan. Yogyakarta:Ar-Ruzz Media.

Berman, A., Snyder, S.J., Kozier, B., Erb, G. 2009. Buku Ajar Praktik keperawatan Klinis Kozier Erb. Jakarta: EGC.

Ernawati. 2016. Data Persalinan Bidan Praktek Swasta Ernawati. Pringsewu.

Gadysa,G.2009.Persepsi Ibu tentang Metode Message. http://luluvikar.wordpress.com/2009/08/26 /persepsi-ibu-tentang-metode- massage.

Manuaba, IBG, dkk. 2010. Ilmu Kebidanan Penyakit Kandungan Dan KB. Jakarta: EGC.

Manuaba. 2013. Ilmu kebidanan dan kandungan. Jakarta: EGC.

Maryunani, Anik. 2010. Nyeri Persalinan. Jakarta: Salemba Medika.

Mender. 2013. Nyeri Persalinan. Jakarta: EGC.
Notoatmodjo, Soekidjo. 2010. Metodologi Penelitian Kesehatan. Jakarta: Rineka Cipta.

Nurasiah, 2012. Asuhan Persalinan Normal Bagi Bidan. Bandung: Refika Aditama.

Smeltzer, S.C \& Bare, B.G. 2012. Buku Ajar Medikal Bedah,Edisi 8 Volume 2. Alih Bahasa Kuncara, H.Y, dkk. Jakarta: EGC.

Sugiyono. 2012. Metode Penelitian Kuantitatif Kualitatif dan $R \& D$. Bandung: Alfabeta.

Wirya Irawan \& Duma Sari,M.2011. Pengaruh Pemberian Massage Punggung dan Tekbik Relaksasi Nafas Dalam Terhadap Penurunan Intensitas Nyeri Pada Pasien Post Appendiktomi Di Zaal C RS HKBP Balige Tahun 2011. Sumatera Utara: Jurnal Keperawatan HKBP Balige. Volume 1 Nomor Juni 2013. ISSN 23383690. 